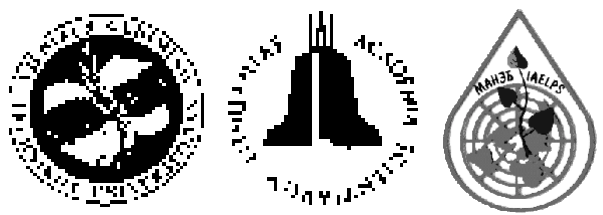

\title{
REMOVAL OF PETROLEUM PRODUCTS FROM WATER USING NATURAL SORBENT ZEOLITE
}

\author{
Aušra Mažeikiene் ${ }^{1}$, Mindaugas Rimeika ${ }^{1}$, Marina Valentukevičienė $\dot{1}^{1}, V_{\text {ytautas }}$ Oškinis $^{2}$, \\ Neringa Paškauskaité2 ${ }^{2}$ Evelina Brannvall ${ }^{2,3}$ \\ ${ }^{1}$ Dept of Water Supply and Management, Vilnius Gediminas Technical University, Sauletekio al. 11, \\ LT-10223Vilnius-40, Lithuania.E-mail: Ausra.Mazeikiene@@ap.vtu.lt \\ ${ }^{2}$ Dept of Environmental Protection, Vilnius Gediminas Technical University, Saulètekio al. 11, \\ LT-10223 Vilnius-40, Lithuania \\ ${ }^{3}$ Dept of Geotechnical Engineering, Vilnius Gediminas Technical University, Sauletekio al. 11, \\ LT-10223Vilnius-40, Lithuania.E-mail: eveli@st.vtu.lt
}

Received 31 May 2005; accepted 28 Sept 2005

\begin{abstract}
An experimental investigation on the removal of petroleum products (PP) from wastewater by natural sorbent zeolite was carried out in a laboratory on a pilot-scaled test bench. The pilot test bench consisted of: a tank in which gasoline (1 portion) and diesel (1 portion) were mixed mechanically with water; a pump for supplying the mixture to a filter model; a filter model filled with a zeolite layer of $0,2 \mathrm{~m}$ height. Zeolite used in this study was from a deposit near the village of Sokyrnytsa in the Ukrainian Transcarpathian region. The test zeolite particle size was $2,5-3,0 \mathrm{~mm} ; 1,5-$ $2,0 \mathrm{~mm} ; 0,63-1,0 \mathrm{~mm}$. The concentration of PP in water was measured before and after the filter every hour. The TOG/ TPH analyser was used for concentration measurements. The experimental study showed that the best adsorption results were reached in the filter with $0,63-1,0 \mathrm{~mm}$ particle size of zeolite media. There were $2,25 \mathrm{mg} / \mathrm{lof}$ light hydrocarbons left in the filtrate. Such a concentration satisfies the requirements of standards regulating the percentage of PP in treated wastewater.
\end{abstract}

Keywords: petroleum products (PP), water pollution, natural sorbent, zeolite.

\section{Introduction}

Petroleum product (PP) pollutant migration in the soil can contaminate huge territories and somewhere it can be hazardous for water sources. An aeration zone connects groundwater with the environment. Rainfall infiltrates through this aeration zone and refreshes groundwater resources. Various pollutants reach the groundwater layer passing through an aeration zone $[1,2]$. Therefore, the main problem and task for today are to stop and minimize dispersion of PP in the geological environment [3-5]. Groundwater contamination by PP is the quantity of light and heavy hydrocarbons in groundwater exceeding the background level. The background level of light hydrocarbons in groundwater is $0,1 \mathrm{mg} / 1$, according to the normative requirements of Lithuania LAND 9-2002.

The requirements mentioned above for environmental risk prevention can be followed by sorbents [6-14]. A detailed study of PP sorption is needed to evaluate the sorp- tion capacity of sorbents. Besides, sorbents have to fit environmental protection requirements: to be easily collected, harmless to the environment, biodegradable and easily utilized [15-20]. A sorbent used in this investigation is natural zeolite.

Natural zeolites are hydrated aluminosilicate minerals of a porous structure with valuable physicochemical properties, such as cation exchange, molecular sieving, catalysis and sorption. Natural clinoptilolite is a zeolite of the heulandite group that is the most abundant in nature. This zeolite contains three channels limited by a system of tetrahedral rings: two channels of eight and ten tetrahedral parallel to $c$ axis of the structure, and a third channel formed by eight member rings and connected to the other two channels. These channels are occupied by water molecules and compensating cations which neutralize the anionic charge of the framework. It is known that multiple use of such materials is based on their physicochemical properties mentioned above what explains a wide range 
of their application in numerous agricultural and industrial areas $[21,22]$.

Natural zeolite - clinoptilolite - is the most abundant in nature and is readily available from more than 40 natural zeolite species. Transcarpathian natural zeolite clinoptilolite - is superior against other natural zeolites due to its greater acid-stability, thermal resistance and mechanical strength. Natural clinoptilolite has a formula $\left[\mathrm{AlSi}_{5} \mathrm{O}_{12}\right]_{2}\left(\mathrm{~K}_{2}, \mathrm{Na}_{2}, \mathrm{Ca}\right)\left(\mathrm{H}_{2} \mathrm{O}\right)_{8}$ where the $\mathrm{Si} / \mathrm{Al}$ ratio in the zeolite structure influences the adsorption properties of clinoptilolite.

Natural clinoptilolite is an ecological, non-toxic material. Thus, it is interesting to find out, if this material is suitable for PP sorption from polluted water.

\section{Object and techniques}

A pilot test bench was constructed for the study of natural zeolite sorption capacity (Fig 1).

The amount of 401 of natural water, 11 of gasoline and 21 of diesel were poured into a 501 plastic container. This mixture was pumped into a mixer in which PP were dissolved, and mechanical stirring got dispersion and emulsive phases in water.

Depending on the existing situation, when the concentration of PP in water is not fixed, during the experiment this concentration varied in the plastic container. It was obtained by addition of filtrate into the plastic container and by gradual solution of PP layer on the water surface.

PP concentration in the water of the mixer increased because of the operation of a mechanical stirrer (4). Usually PP removal filters are installed insomuch that the PP layer in the precipitator remains on the water surface. This PP layer dissolves in time, and the concentration of PP in the precipitator increases. Thus, the experiment on the re-

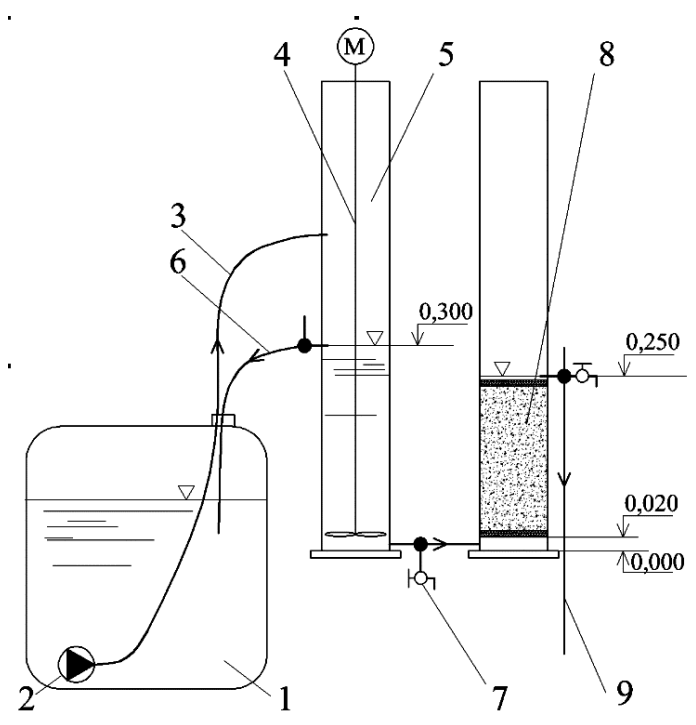

Fig 1. Pilot test bench: 1 - plastic container, 2 - pump; 3 - flexible hose; 4 - mechanical stirrer; 5 - mixer; 6 flexible hose for excessive water amount; 7 - sample mixer tap; 8 - zeolite filter media; 9 - filtrate moval of PP from water was carried out at unstable primary concentrations because of the reasons mentioned above.

Samples for the determination of PP concentrations in the experimental solution were taken from a sample mixer tap. In the filter media water with PP was filtered through a $20 \mathrm{~cm}$ zeolite layer. PP concentrations were measured in the samples from the filtered water as well. Three different sizes of zeolite particles were used in this study: 0,63-1,0 mm; 1,5-2,0 $\mathrm{mm}$ and 2,5-3 mm. Natural zeolite was washed and dried at $105{ }^{\circ} \mathrm{C}$ temperature in an oven before using it in the filter bed.

The filtration process was started at a filtration rate of $2 \mathrm{~m} / \mathrm{h}$, and experiments were stopped, when marginal pressure losses were reached, and the quality of filtrate was not acceptable. PP concentrations in the experimental water before filter from the mixer and filtrate samples was measured every hour, five times each. TOG/TPH analyser was used for the detection of PP concentrations in water and filtrate samples. The Model HATR-T Infracal TOG/ TPH Analyzer is designed as an alternative for EPA Methods 413,2 and 418,1 that use Freon in the extraction procedure as well as for other applications where the concentration of a sample dissolved in an infrared transparent solvent is to be measured. Individual samples are prepared using the Hexane extraction procedure. To determine content using the Hexane extraction procedure and the Infracal TOG/TPH Analyser, Model HATR-T, the sample is placed in the trough of the IR Platform. The Infracal IR Platform can provide quantitative information on oil and grease residue left on the reflecting surface after the hexane extractant has evaporated.

\section{Experimental results}

Experimental study was carried out in January - April 2005 . First of all a fraction of 1,5-2,0 mm of natural zeolite was used in this study. Experimental water contaminated with PP was filtered at a filtration rate of $5 \mathrm{~m} / \mathrm{h}$. Dependence of PP concentrations in filtrates on those in experimental water before filters is shown in Figs 2, 4, 6 .

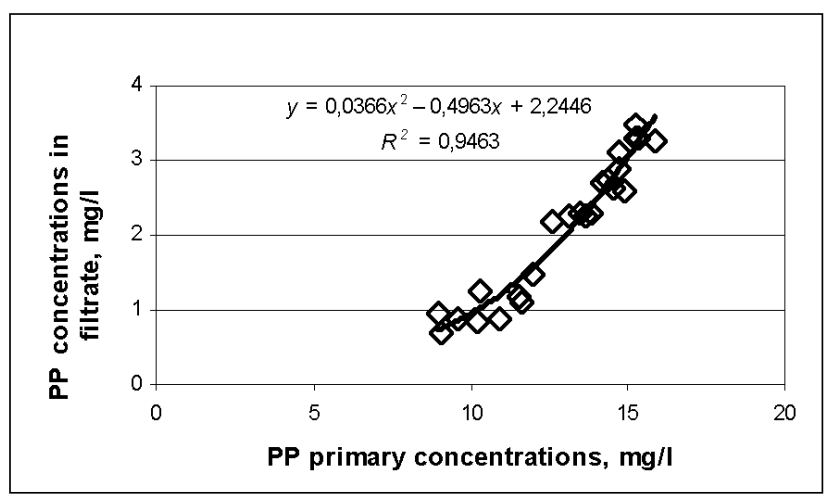

Fig 2. Dependence of PP concentrations in filtrate on their concentrations in primary solution before filter for filter media natural zeolite particle size of $1,5-2,0 \mathrm{~mm}$ 
PP concentrations in water before the filter (further called "primary concentration") varied from 8,96 to 15,85 $\mathrm{mg} / \mathrm{l}$, and, respectively, those in filtrate - from 0,7 to 3,5 $\mathrm{mg} / \mathrm{l}$. Dependence of PP concentrations of in filtrate on their primary concentrations is polynomial, and the coefficient of determination $R^{2}=0,9463$.

The efficiency of the removal of gasoline and diesel pollutants from water by natural zeolite with 1,5-2,0 mm particle size was 76-92\%, and it is calculated that the concentration of PP in water after filtration decreased 5-11 times. According to the requirements, such a cleaned water can be drained into a domestic wastewater system because the concentration of PP in water doesn't exceed $10 \mathrm{mg} / \mathrm{l}[1]$.

According to the results, the parameters of an adsorption equation were calculated. Mathematical expression of adsorption dependence is:

$$
q_{s}=a_{F} C_{s}^{b F},
$$

where

$q_{s}$ - adsorbed quantity of PP, $\mathrm{mg} / \mathrm{g}$ of adsorbent; $C_{s}$ - equilibrium concentration of adsorption material in the solution; $a_{F}$ and $b_{F}-$ adsorption constants; $\mathrm{a}_{\mathrm{F}}$ sorption capacity of adsorbent, $\mathrm{ml} / \mathrm{g} ; b_{F}$ - nondimensional constant defining homogeneity of chemical composition of adsorbent (the value varies between 1 and 0 ; when homogeneity decreases, the value of constant vanishes).

Dependence of adsorption for an adsorption material of natural zeolite with $1,5-2,0 \mathrm{~mm}$ particle size is shown in Fig 3.

In this case the constant $a_{F}=1,9338 \mathrm{mg} / \mathrm{l}$. The higher $a_{F}$, the better adsorption results; therefore, 2,5-3,0 $\mathrm{mm}$ and $0,63-1,0 \mathrm{~mm}$ zeolite particle size was used for adsorption comparison.

Further, in this experimental study $2,5-3,0 \mathrm{~mm}$ fraction of natural zeolite was used. Dependence of PP concentrations in filtrate on their primary concentrations is shown in Fig 4.

The primary concentrations of $\mathrm{PP}$ in water vary from $6,8 \mathrm{mg} / 1$ to $15,1 \mathrm{mg} / \mathrm{l}$.

$4,5-14,0 \mathrm{mg} / 1$ of PP remain in filtrate, so the efficiency of PP removal from water was $10-38 \%$. Depen-

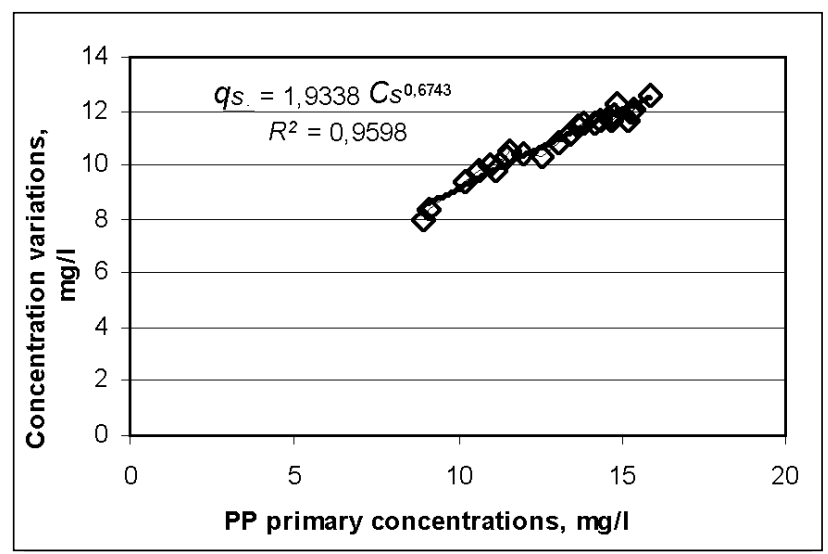

Fig 3. Dependence of adsorption for natural zeolite particle size of $1,5-2,0 \mathrm{~mm}$

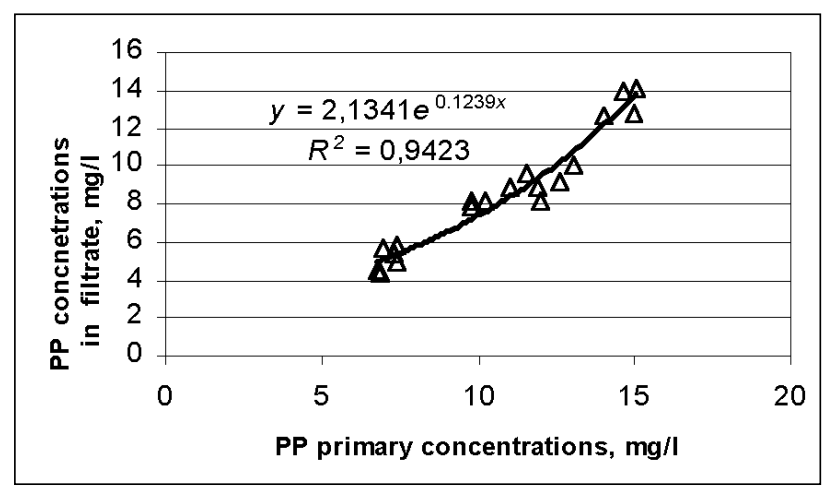

Fig 4. Dependence of PP concentrations in filtrate on their primary concentrations for filter media natural zeolite particle size of $2,5-3,0 \mathrm{~mm}$

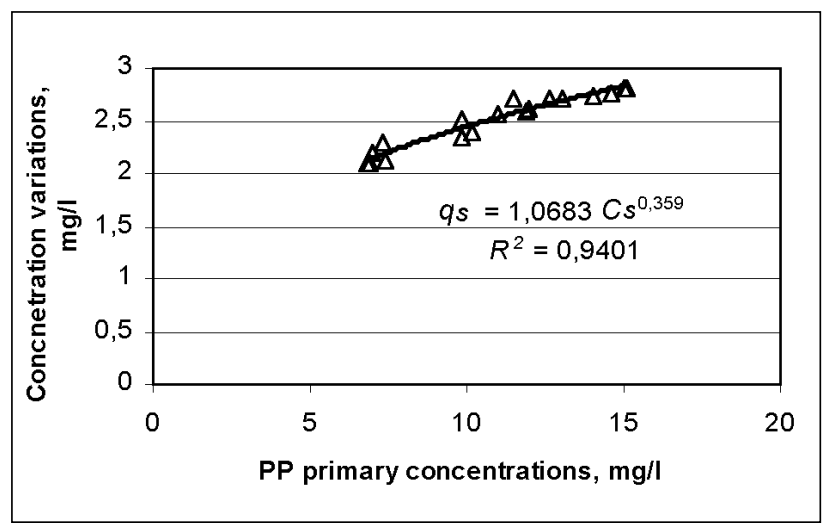

Fig 5. Dependence of adsorption for natural zeolite particle size of $2,5-3,0 \mathrm{~mm}$

dence of PP concentrations in filtrate on their primary concentrations is exponential, and the coefficient of determination $R^{2}=0,9423$. Natural zeolite with 2,5-3,0 $\mathrm{mm}$ particle size removes PP from water worse than 1,5-2,0 mm zeolite fraction. However, both studied zeolite fractions decrease PP concentrations in water up to a desirable $10 \mathrm{mg} / 1$ limit.

Dependence of adsorption for an adsorption material of natural zeolite with 2,5-3,0 $\mathrm{mm}$ particle size is shown in Fig 5.

In this case the constant $a_{F}=1,068 \mathrm{mg} / \mathrm{l}$. It is lower than that for zeolite with $1,5-2,0 \mathrm{~mm}$ particle size, thus the adsorption results were worse.

The experiment was continued with the zeolite particle size of $0,63-1,0 \mathrm{~mm}$. Dependence of PP concentrations in filtrate on their primary concentrations is shown in Fig 6.

The polynomial relationship of the data and the coefficient of determination $R^{2}=0,9764$ are shown in this figure. As the primary concentrations of PP in water varied from 8,82 to $15,35 \mathrm{mg} / 1,0,48-2,25 \mathrm{mg} / \mathrm{l}$ of PP remained in filtrate. The efficiency of PP removal from water reached $85-94 \%$. The highest efficiency was at the beginning of the experiment (during the first 13 hours) - 91-94\%. At that moment the concentration of PP in filtrate was $<1 \mathrm{mg} / \mathrm{l}$. That is a concentration which is lower than MTP 


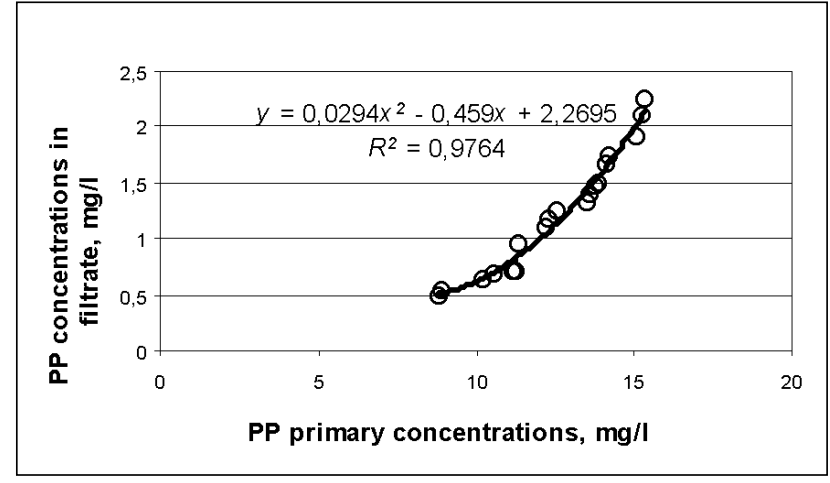

Fig 6. Dependence of PP concentrations in filtrate on their concentration in primary solution before filter for filter media natural zeolite particle size of $0,63-1,0 \mathrm{~mm}$

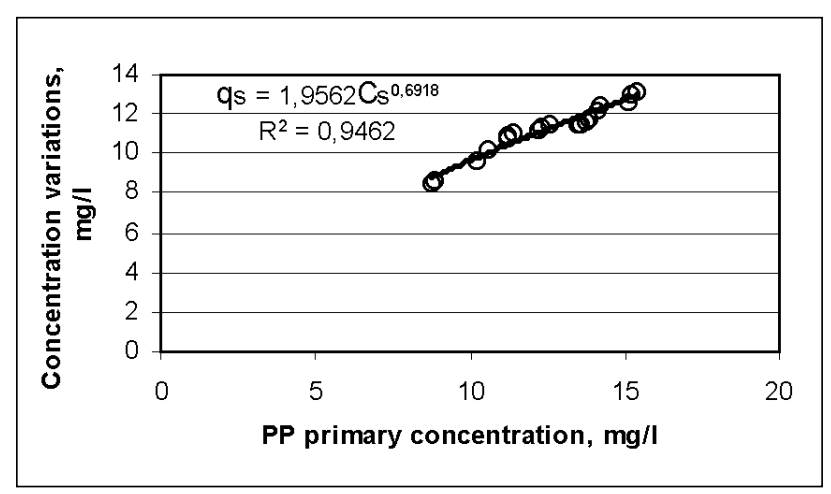

Fig 7. Dependence of adsorption for natural zeolite particle size of $0,63-1,0 \mathrm{~mm}$

(Maximum Temporary Permissible) concentration in groundwater contaminated with PP in the territories of A and $\mathrm{B}$ categories, according to sensitivity to pollution [1].

Dependence of adsorption for an adsorption material of natural zeolite with $0,63-1,0 \mathrm{~mm}$ particle size is shown in Fig 7.

In this case the constant $a_{F}=1,9562 \mathrm{mg} / 1$. It is higher than that for zeolite fractions with $1,5-2,0 \mathrm{~mm}$ and 2,53,0 $\mathrm{mm}$ particle size. The results of adsorption were the best using the finest fraction.

When PP primary concentrations increased, their concentrations in filtrate increased as well. The best results for PP removal from water were achieved using zeolite with a particle size of $0,63-1,0 \mathrm{~mm}$ because even after 32 hours of filtration the concentration of PP in filtrate remained $2,25 \mathrm{mg} / \mathrm{l}$.

\section{Conclusions}

1. Natural zeolite with a various particle size $(2,5-$ $3,0 \mathrm{~mm} ; 1,5-2,0 \mathrm{~mm} ; 0,63-1,0 \mathrm{~mm}$ ) is able to decrease the concentrations of PP in water by the sorption process.

2. The efficiency of PP removal from water depends on the particle size of zeolite, the primary concentrations of PP and the duration of the filtration process.

3. During the first 13 hours of filtration the most effi- cient natural zeolite with a particle size of $0,63-1,0 \mathrm{~mm}$ removed from water $91-95 \%$ of gasoline and diesel pollutants. When the primary concentrations of PP in water were $8,82-12,25 \mathrm{mg} / \mathrm{l}$, less than $1 \mathrm{mg} / \mathrm{l}$ of PP was left in filtrate. Such a concentration is lower than MPL (Maximum Permissible Level) for oil hydro-carbonates in groundwater for territories of A and B categories, depending on sensitivity to pollution.

4. When the duration of filtration cycles was $30 \mathrm{~h}$ and the filtration rate was $5 \mathrm{~m} / \mathrm{h}$, all the zeolite fractions $(2,5-$ $3,0 \mathrm{~mm} ; 1,5-2,0 \mathrm{~mm} ; 0,63-1,0 \mathrm{~mm}$ ) decreased the quantity of PP up to less than $10 \mathrm{mg} / 1$.

5. The experimental results show that all fractions of natural zeolite can be used for the removal of PP from water in the chemical and oil industry, gasoline stations, etc. Treated wastewater can be released into domestic wastewater systems or natural surface water bodies.

\section{References}

1. LAND 9-2002. The requirements on treatment of soil and groundwater polluted with oil products and pollution limits. Ministry of Environment of Lithuania. 2002, p 31 (in Lithuanian).

2. Marcinonis, A. et al. Results of ecohydrogeological investigation and groundwater monitoring network implementation in JS „Lietuvos kuras“ gas stations. UAB „Grota“. Vilnius, 1999, p 5-20 (in Lithuanian).

3. Marcinonis, A. et al. Hydrogeological recommendations for the ecological situation improvement and remediation of groundwater polluted with oil. UAB „Grota“. Vilnius, 1998, p 3-14 (in Lithuanian).

4. Marcinonis, A.; Paukštys, B. Oil products - hazardous fresh groundwater pollution source. In: Geosciences. Lithuanian Academy of Sciences. Vilnius, 1999, p 15-8 (in Lithuanian).

5. http://carbtrol.com/water\&waste.pdf.

6. http://traidenis.lt/produkcija/absorb/absorb.htm.

7. http://www.filtreja.lt/index.php? $\operatorname{lng}=1 \mathrm{t} \&$ content $=$ pages\&pageid $=117$

8. http://www.filtreja.lt/index.php?lng=lt\&content=pages\&page $\mathrm{id}=118$

9. http://www.makrosprendimai.com/projects/elega/naudojimosritys.html

10. http://www.dormeka.lt/sorbentai.html

11. http://www.chemija.ctf.ktu.lt/zurnalas/KC-20-liet.htm

12. http://www.aquariacentral.com/forums/archive/index.php/t4576.html.

13. http://www.gasolitech.com/wt1.html.

14. http://www.gasolitech.com/wt2.html.

15. Lange K. Robert. Surfactants: A Practical Handbook. USA: Hanser Gardner Publications, 1999, p 16-43.

16. Akselrub, G. A.; Altšuler, M. A. Introduction to capilarchemical technology. Moscow: Chemistry, 1983, p 21-38 (in Russian).

17. http://www.chemija.ctf.ktu.lt/zurnalas/KC-08-liet.htm

18. Klimantavičiūtė, M. G.; Šalkauskas, M.; Virbalytė, D.; 
Juršènas, R. Lead and cadmium sedimentation from solutions by cement dust. Environmental Engineering (Aplinkos inžinerija), Vol IX, No 1. Vilnius: Technika, 2001, p 42-51.

19. Baltrènas, P.; Paliulis, D.; Vaišis, V. Investigation of oil spill biosorbent SPHAG-SORB. Environmental Engineering (Aplinkos inžinerija), Vol X, No 3. Vilnius: Technika, 2002, p 103-107 (in Lithuanian).

20. Vengris, T.; Binkienè, R.; Kaušpėdienè, D. Lithuanian glauconite sorption characteristics. Environmental Engineering and Management (Aplinkos tyrimai, inžinerija ir vadyba),
No 1(4), Kaunas: Technologija, 1997, p 37-41.

21. Sakalauskas, A.; Valentukevičienè, M. Investigation into the influence of natural powdered zeolite on drinking water treatment at Druskininkai waterworks III. Journal of Environmental Engineering and Landscape Management, Vol XI, No 4. Vilnius: Technika, 2003, p 169-178.

22. Valentukevičienè, M.; Jankauskas, J. Experimental comparative investigation on adsorption capacity of natural powdered adsorbents (zeolites) and activated powdered carbon. Environmental Engineering (Aplinkos inžinerija), Vol IX, No 4. Vilnius: Technika, 2002, p 217-222.

\title{
NAFTOS PRODUKTŲ ŠALINIMAS IŠ VANDENS NAUDOJANT NATŪRALŲJİ SORBENTĄ CEOLITĄ
}

\author{
A. Mažeikienė, M. Rimeika, M. Valentukevičienė, \\ V. Oškinis, N. Paškauskaitė, E. Brannvall
}

$\mathrm{S}$ a $\mathrm{n} \mathrm{tr}$ a u k a

Gamtinio ceolito geba šalinti iš vandens naftos produktus tirta sumontuotame eksperimentiniame stende. Stendą sudarè: bakas, kuriame mechaniškai maišant benzinas (1 dalis) ir dyzelinas (1 dalis) skiedžiamas vandenyje; siurblys, tiekiantis tirpalą i filtro modeli; filtro modelis, $0,2 \mathrm{~m}$ sluoksniu pripildytas ceolito. Tyrimams pasirinktas i Lietuvą iš Ukrainos atvežamas Sokirnicos radimvieteje kasamas ceolitas. Eksperimentuojant naudotos 2,5-3,0 mm; 1,5-2,0 mm; 0,63-1,0 mm stambumo ceolitu grūdeliu frakcijos. Naftos produktų koncentracija vandenyje prieš filtrą ir filtrate buvo nustatoma kas valandą analizatoriumi TOG/TPH. Eksperimentiniai tyrimai atlikti $2005 \mathrm{~m}$. sausio - balandžio mènesiais. Kaip matyti iš tyrimo duomenu, geriausiai naftos produktus adsorbavo 63-1,0 mm stambumo ceolito grūdelių frakcijos užpildas. Filtrate likdavo 2,25 mg/l naftos produktų koncentracija. Tai pagal ištirpusių naftos produktų koncentraciją atitinka į nuotekų tinklus išleidžiamam vandeniui keliamus normatyvinius reikalavimus.

Raktažodžiai: naftos produktai, vandens teršimas, natūralusis sorbentas ceolitas.

Aušra MAŽEIKIENĖ. Dr, Assoc Prof, Dept of Water Supply and Management, Vilnius Gediminas Technical University (VGTU).

Publications: author (with co-authors) of more than 10 research papers. Research interests: biological methods for water treatment, wastewater sludge analysis. (VGTU).

Mindaugas RIMEIKA. Dr, Assoc Prof, Dept of Water Supply and Management, Vilnius Gediminas Technical University

Doctor of Science (environmental engineering) VGTU, 2000. Publications: author (with co-authors) of more than 10 reseach papers.

Marina VALENTUKEVIČIENĖ. Dr, Assoc Prof, Dept of Water Supply and Management, Vilnius Gediminas Technical University (VGTU).

Doctor of Science (environmental engineering), VGTU, 2003. Publications: author (with co-authors) of more than 10 research papers and 1 invention. Research interests: water and waste water treatment technologies, sludge treatment, environmental engineering, water supply and management, water law regulations.

Vytautas OŠKINIS. Dr, Assoc Prof, Dept of Environmental Protection, Vilnius Gediminas Technical University (VGTU).

Doctor of Natural Sciences (biology; ecology), Institute of Ecology, 1993. Publications: author of about 50 scientific publications. Research interests: applied ecology, environmental pollution.

Neringa PAŠKAUSKAITĖ. Master student, Vilnius Gediminas Technical University (VGTU).

Evelina BRANNVALL. Master, doctoral student (since 2002), Dept of Environmental Protection, Vilnius Gediminas Technical University (VGTU).

Employment: asisstant, Dept of Geotechnical Engineering, VGTU. Publications: co-author of 2 monographs, over 10 research papers and 1 invention. Research interests: technogenic geochemistry, soil remediation by using natural materials. 